\title{
Vapour-tight layer and its effect on surface temperatures of curtain walling
}

\author{
Petr Kacálek ${ }^{1, *}$ and Tomáš Petř́íček ${ }^{1}$ \\ ${ }^{1}$ Brno University of Technology, Faculty of Civil Engineering, \\ Institute of Building Structures, Veveří 95, 60200 Brno, Czech Republic
}

\begin{abstract}
The primary function of a vapour-tight layer is to reduce or prevent the spread of humidity from the interior to other layers of the surrounding structures. This would otherwise result in condensation of (water) vapour due to a drop in temperature. In some cases, the behaviour of real structures differs from the structure modelled using a computational programme. This paper deals with the factors that can affect the features of a structure, specifically the internal and external surface temperature of curtain walling. The heat reflection effect of a vapour-tight layer was investigated on a model panel of curtain walling. An inadequate surface temperature can have a negative impact in that it promotes a biotic attack. This results in surface degradation which affects the continuous layers in the adjacent structures.
\end{abstract}

\section{Introduction}

The interest in prefabricated wooden houses has grown over time. They have recently become the most popular type of residential house. In this type of building, it is necessary to not only protect the timber elements, but also a number of specific constructional details, as well as provide a vapour-tight barrier from the external wall. Vapour-tight barriers in wooden sandwich constructions are usually one of various types of PE foil. Another option is to use PE foil with a thin layer of aluminium for effective heat reflection. The application of the appropriate vapour-tight layer can have a significant influence on the final surface temperature of the structures.

Due to the sealing of the building's envelopes, surface humidity from condensation or even the growth of mould on the structure's surface is often encountered. In the majority of cases the cause is the inappropriate use of interior materials. However, there are other, less significant factors that can also affect the behaviour of the structure.

An inadequate surface temperature can have a negative impact in that it promotes a biotic attack on the structures of a prefabricated wooden house. The result is surface degradation which affects the continuous layers in adjacent structures. In some cases, the

\footnotetext{
${ }^{*}$ Corresponding author: kacalek.p@,fce.vutbr.cz
} 
behaviour of the real structure can differ from the behaviour of the structure modelled using a computational programme.

The research conducted in this paper is based on a sandwich test panel (made up of two parts) constructed using real wooden house curtain walling with two types of vapour-tight foil (standard PE foil and reflective multilayer bubble foil) and a plasterboard lining. The surface temperature was measured using thermocouples placed in comparable positions on both halves of the panel i.e. with the standard or reflective vapour-tight foil. The effect of using an aluminium reflective layer on one of the parameters was monitored in order to evaluate the quality of the indoor environment - internal surface temperature of the curtain walling.

\section{Methodology and course of the experiment}

The testing of the properties of the vapour-tight layers involved contact measurement of the surface temperature of the two halves of the test panel using thermoelectric surface sensors (thermocouples). During the contact measurement, the temperature sensors were in direct contact with the surface being measured. The method for attaching the sensor to the surface was chosen so that the temperature of the surface was not influenced by the sensor and the sensor was in direct contact with the surface. The measurement process was split into two phases. In the first phase, the measurement was only taken on the plasterboard lining of the curtain walling. In the second phase, the subject of the measurement was the complete structure i.e. the curtain walling of the prefabricated wooden structure and the plasterboard lining (see Figure 1).

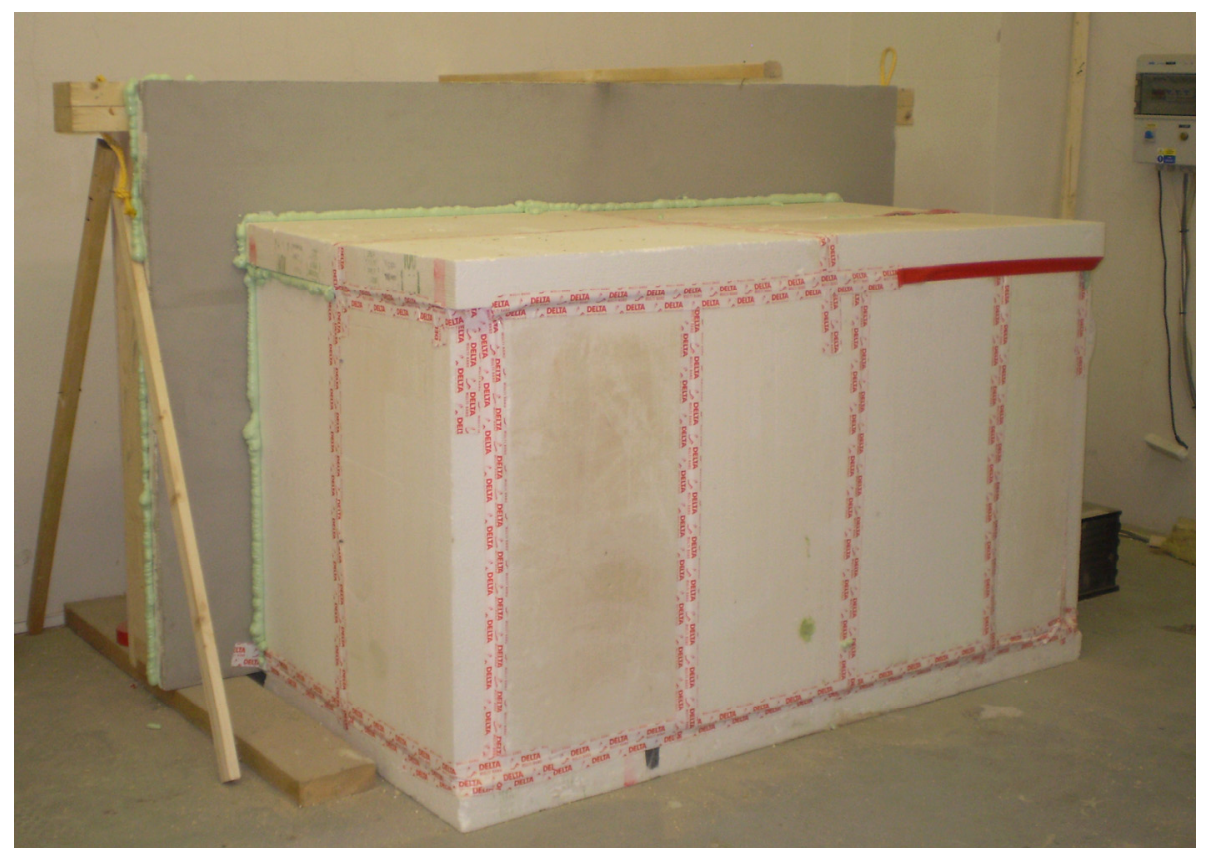

Fig. 1. Curtain walling test panel of the prefabricated wooden building structure.

On one half of the test panel, a vapour-tight layer made of multilayer bubble foil with an aluminium reflective layer (REF) was applied, and on the other half of the panel, a vapourtight layer without a reflective layer (STANDARD) was applied. During the measurement process, the transient temperature of the external environment was simulated. 


\section{Experimental measurements}

The test panel, complete curtain walling and plasterboard lining, with the dimensions $3 \mathrm{x}$ $1.5 \mathrm{~m}$ (see Figures 2 and 3) was installed in the test laboratory at the Institute of Building Structures. The two halves of the panel were tested by simulating the transient temperature, whereby the external temperature (Te) in the range of $(-15) \pm 1^{\circ} \mathrm{C}$ to $(-18) \pm 1^{\circ} \mathrm{C}$ and the internal temperature (Ti) $21 \pm 1^{\circ} \mathrm{C}$. The monitored values (panel surface temperature, internal and external environment temperatures) were recorded at 10-minute intervals.

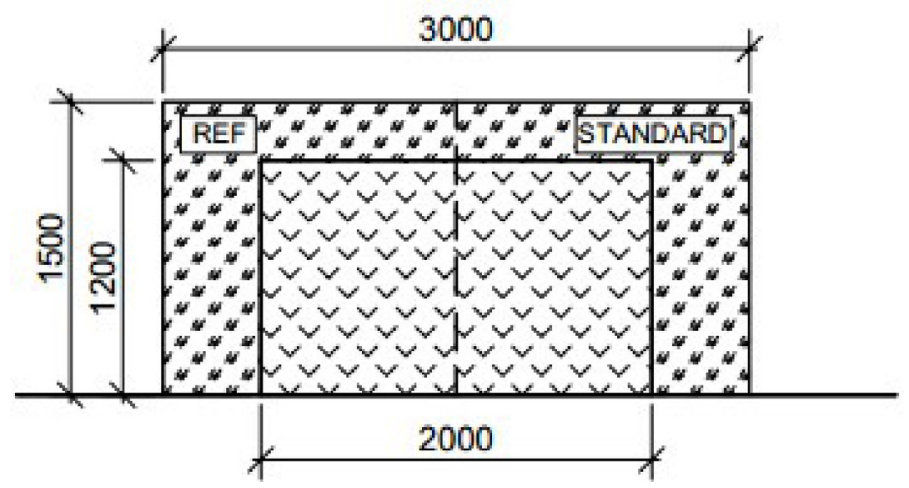

Fig. 2. (Two halves of the) test panel [1].

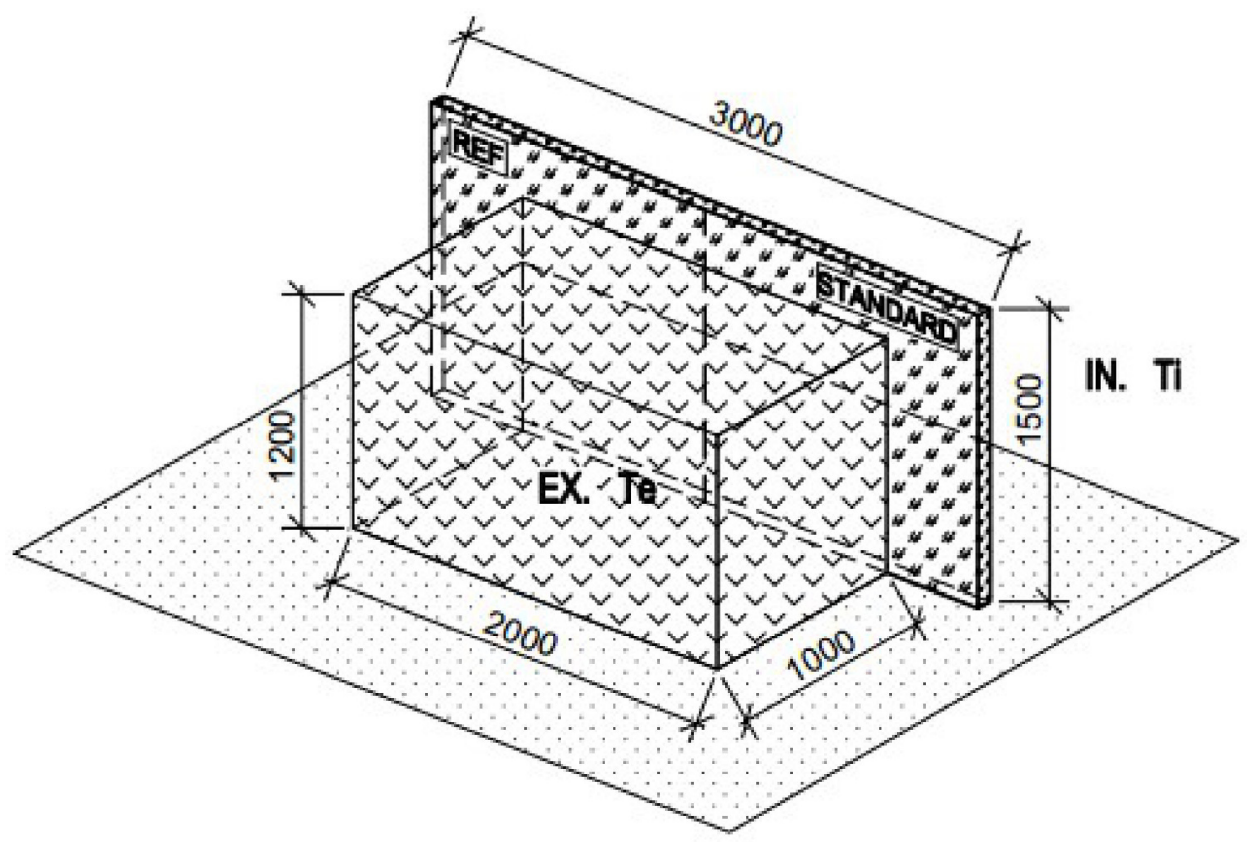

Fig. 3. 3D view of the test panel [1].

The structures of the two halves of the test panel are shown in Figures 4 and 5. 
When applying the reflective vapour-tight barrier with aluminium layer, a nonventilated air gap of at least 25 (30) mm thickness must be created in front of the barrier. This allows the reflection of the heat back into the interior.

For the two halves of the test panels, the structure of the interior plasterboard lining (see Figure 4), as well as the complete structure with curtain walling (see Figure 5), were constructed in the same way they are commonly installed in real structures for prefabricated wooden houses.

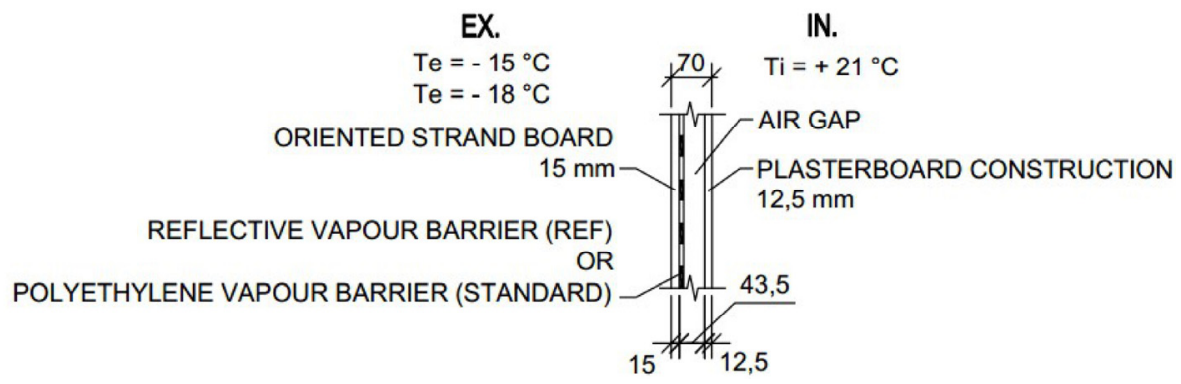

Fig. 4. Composition of test panel - plasterboard lining.

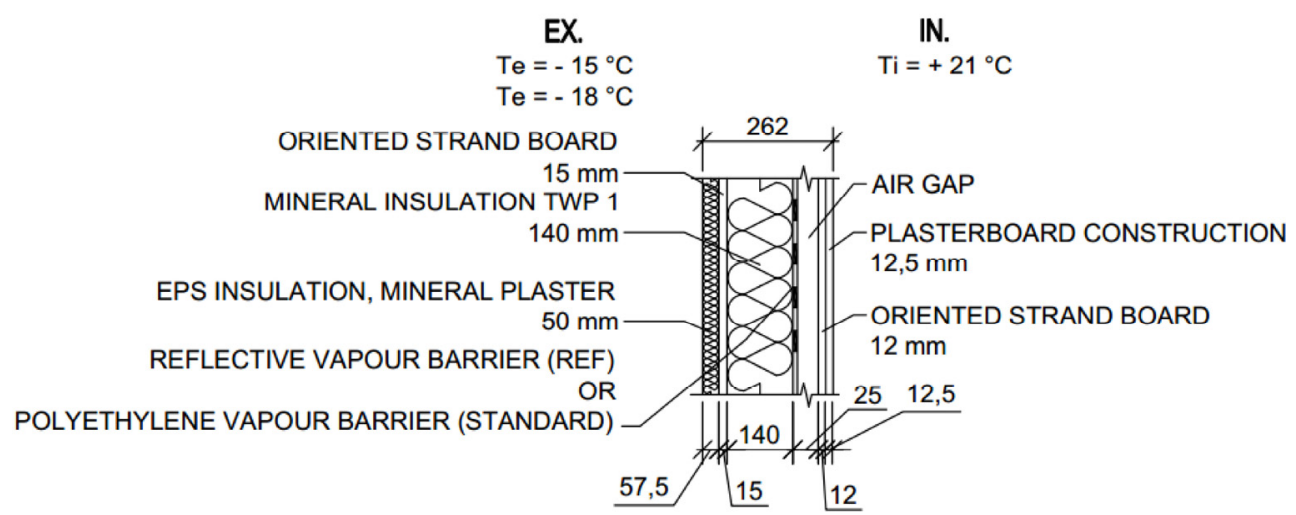

Fig. 5. Composition of test panel - curtain walling and plasterboard lining.

\section{Experimental measurements results}

The experiment provided four sets of results - for two types of barrier and two external temperatures. The results are presented in Tables 1 and 2.

The temperature difference observed on the external surface of the plasterboard lining with the reflective foil applied was about one third higher compared to the temperature measured on the wall on which only PE vapour-tight foil was applied. During the measurements, when the ambient temperature was $\mathrm{Te}=-150 \mathrm{C}$ (see Table 1), the temperature on the surface where the foil with the aluminium reflective layer was applied was $33.6 \%$ higher (from $21.7^{\circ} \mathrm{C}$ to $29^{\circ} \mathrm{C}$ ). In other words, the application of the foil significantly increased the thermal resistance of the wall. 
Table 1. Results of measuring surface temperature of plasterboard lining [2].

\begin{tabular}{|c|c|c|c|c|c|}
\hline \multicolumn{2}{|l|}{ Cold side of the wall (EX.) } & \multicolumn{3}{|c|}{ Warm side of the wall (IN.) } \\
\hline \multirow{2}{*}{$\begin{array}{c}\text { Temperature } \\
\mathrm{Te}\left({ }^{\circ} \mathrm{C}\right)\end{array}$} & \multicolumn{2}{|c|}{ Surface temperature $\left({ }^{\circ} \mathrm{C}\right)$} & \multirow{2}{*}{$\begin{array}{c}\text { Temperature } \\
\mathrm{Tin}\left({ }^{\circ} \mathrm{C}\right)\end{array}$} & \multicolumn{2}{|c|}{ Surface temperature $\left({ }^{\circ} \mathrm{C}\right)$} \\
\cline { 2 - 3 } & $\begin{array}{c}\text { polyethylene } \\
\text { barrier }\end{array}$ & $\begin{array}{c}\text { Reflective } \\
\text { barrier }\end{array}$ & & $\begin{array}{c}\text { polyethylene } \\
\text { barrier }\end{array}$ & $\begin{array}{c}\text { Reflective } \\
\text { barrier }\end{array}$ \\
\hline-15.0 & -7.4 & -13.3 & 21.0 & 14.3 & 15.7 \\
\hline-18.0 & -9 & -15.6 & 21.0 & 14.3 & 15.7 \\
\hline
\end{tabular}

In terms of curtain walling test panel, the thermal insulator in the structure has a significant influence. The difference in temperatures measured on the surface of the curtain walling where the reflective foil was applied was negligible compared to the wall on which only the PE vapour-tight foil was applied. During the measurements, when the ambient temperature was $\mathrm{Te}=-15^{\circ} \mathrm{C}$ (see Table 2), the application of the foil with the aluminium reflective layer increased the temperature difference from $32.42{ }^{\circ} \mathrm{C}$ to $34.02{ }^{\circ} \mathrm{C}$ i.e. by $5 \%$.

Table 2. Results of measuring surface temperatures of curtain walling test panel.

\begin{tabular}{|c|c|c|c|c|c|}
\hline \multicolumn{2}{|l|}{ Cold side of the wall (EX.) } & \multicolumn{3}{|l|}{ Warm side of the wall (IN.) } \\
\hline \multirow{2}{*}{$\begin{array}{c}\text { Temperature } \\
\mathrm{Te}\left({ }^{\circ} \mathrm{C}\right)\end{array}$} & \multicolumn{2}{|c|}{ Surface temperature $\left({ }^{\circ} \mathrm{C}\right)$} & \multirow{2}{*}{$\begin{array}{c}\text { Temperature } \\
\mathrm{Ti}\left({ }^{\circ} \mathrm{C}\right)\end{array}$} & \multicolumn{2}{|c|}{ Surface temperature $\left({ }^{\circ} \mathrm{C}\right)$} \\
\cline { 2 - 3 } \cline { 5 - 6 } & $\begin{array}{c}\text { Polyethylene } \\
\text { barrier }\end{array}$ & $\begin{array}{c}\text { Reflective } \\
\text { barrier }\end{array}$ & & $\begin{array}{c}\text { Polyethylene } \\
\text { barrier }\end{array}$ & $\begin{array}{c}\text { Reflective } \\
\text { barrier }\end{array}$ \\
\hline-15.0 & -13.81 & -15.33 & 21.0 & 18.61 & 18.69 \\
\hline-18.0 & -15.86 & -18.38 & 21.0 & 18.65 & 18.74 \\
\hline
\end{tabular}

\section{Conclusion}

By experimenting with plasterboard lining and curtain walling test panels, the effect of a vapour-tight barrier with applied reflective aluminium layer was investigated. On the basis of the measured values, it is clear that the application of a multi-layer bubble foil with aluminium reflective layer does not significantly influence the internal surface temperatures of curtain walling with common heat insulation.

From the results of the measurements taken on the real curtain walling panel (see Table 2) it is clear that the application of the foil with the reflective layer has a significant effect on the external side of the wall where the temperature difference is ca. $1.5^{\circ} \mathrm{C}$. The effect of the application of the reflective foil on the internal side of the wall is only slight compared to the total composition of the curtain walling, whereby the application of mineral heat insulation between the load-bearing columns has a significant effect on the thermal gradient. 
The "light" vapour-tight layers do not significantly improve the thermal characteristics of the structure, especially the internal surface temperature which significantly determines the formation of biotic attack on the surface of the structure. Emphasis should therefore be placed on the incorporation of a high quality vapour-tight layer into the structure. The most important things are to avoid construction errors, to ensure perfect connections to passages, and other important details (e.g. threshold connector - [3]. etc.). Another important factor is that the vapour-tight layer must be of sufficient mechanical strength, which is influenced by the lining layer and the individual joints of the vapour-tight layers [4-6].

This paper has been worked out under the project No. LO1408 "AdMaS UP - Advanced Materials, Structures and Technologies", supported by Ministry of Education, Youth and Sports under the „National Sustainability Programme I”.

\section{References}

1. P. Kacálek, R. Smolka, T. Petříček, Juniorstav 2011 (Akademické nakladatelství CERM, Brno, 2011)

2. H. Marková, P. Kacálek, J. Hejhálek, Českomoravský výběr (Vega s.r.o., Hradec Králové, 2009)

3. R. Smolka, J. Plachý, P. Kacálek, T. Petrríček, AMM 824, 188-195 (2016)

4. T. Petř́ček, P. Kacálek, R. Smolka, AMR 1041, 71-74 (2014)

5. CSN EN ISO 10211, Thermal bridges in building construction-Heat flows and surface temperatures - Detailed calculations (Czech office for standards, metrology and testing, Prague, 2009)

6. CSN EN ISO 13788, Hygrothermal performance of building components and building elements - Internal surface temperature to avoid critical surface humidity and interstitial condensation - Calculation methods (Czech office for standards, metrology and testing, Prague, 2013) 